\title{
Impact of dietary protein on lipid metabolism in hamsters is source-dependent and associated with changes in hepatic gene expression
}

\author{
Alfred Aziz, Chao Wu Xiao, Kevin A. Cockell, G. Sarwar Gilani, Cristina Cruz-Hernandez and W. M. Nimal \\ Ratnayake* \\ Nutrition Research Division, Food Directorate, Health Products and Food Branch, Health Canada, PL 2203E, 251 Sir Frederick \\ Banting Driveway, Ottawa K1A 0K9, ON, Canada
}

(Received 4 June 2007 - Revised 3 December 2007 - Accepted 3 December 2007 - First published online 29 January 2008)

This study tested the hypothesis that protein source is a factor determining the impact of the diet on lipid metabolism in hamsters. Twenty-eight hamsters of similar body weight were assigned for a period of 8 weeks to one of the following four diets (seven per group) containing either $20 \%$ $(\mathrm{w} / \mathrm{w})$ casein $(\mathrm{CAS})$, beef protein $(\mathrm{BF})$, wheat gluten $(\mathrm{WG})$ or soya protein (SOY). The fat composition of the diet was the same (15.5\% w/w) in all groups and provided SFA, MUFA and PUFA representative of the average Canadian diet. After an overnight fast, blood and liver were collected for the measurement of serum lipids, fatty acid composition of liver phospholipids and mRNA levels of selected genes involved in lipid metabolism. WG resulted in lower total cholesterol, HDL-cholesterol and non-HDL-cholesterol but, along with SOY, in higher mRNA levels of cholesterol $7 \alpha$-hydroxylase and LDL receptor. Furthermore, both WG and SOY resulted in lower 18:3n-3, 20:4n-6, total $n$ - 6 PUFA, 18: $1 n$-9 and total MUFA, but higher $22: 6 n-3$, total $n-3$ PUFA, $22: 6 n-3 / 18: 3 n-3$ and $22: 5 n-3 / 18: 3 n-3$ ratios in liver phospholipids, and higher hepatic $\Delta 6$-desaturase mRNA levels. These results show that the impact of dietary protein on lipid metabolism is source-dependent and associated with changes in mRNA abundances of key hepatic enzymes and receptors.

Lipid metabolism: Fatty acids: Cholesterol: Gene expression: Hamsters

CVD are the leading causes of death in $\mathrm{Canada}^{(1)}$ and incur tremendous costs for the Canadian health care system ${ }^{(2)}$. Therefore, primary prevention is the ultimate strategy warranted to reduce the rate of mortality from CVD and alleviate the economic burden of its morbidities. Defective lipid metabolism is a cluster of modifiable risk factors for CVD, including hypercholesterolaemia (total cholesterol (TC) and LDL-cholesterol (LDL-C)), hypertriacylglycerolaemia and low circulating concentrations of HDL-cholesterol (HDL-C), that can be corrected by diet.

The impact of the three classes of macronutrients on lipid metabolism has been investigated to various degrees, with that of dietary fats and cholesterol receiving the greatest attention $^{(3)}$. Recent years have witnessed a surge in the popularity of high-protein diets for the management of body weight in obesity $^{(4)}$. These diets were shown to be effective not only in inducing weight loss ${ }^{(5)}$, but also in improving lipid profile and reducing CVD risk ${ }^{(6)}$. However, these and other effects appear to be dependent on the source of protein ${ }^{(7,8)}$. It is generally agreed that vegetable protein decreases circulating cholesterol concentrations compared to animal protein ${ }^{(9,10)}$.

The limitations of most of these studies are the comparison of the effects of only two sources of protein at a time on lipid indices, the use of an animal model whose lipid metabolism in response to diet differs from that of man, and large variations in the quantity and quality of dietary lipids. The majority of studies compared the effects of soya protein (SOY) and casein $(\mathrm{CAS})^{(10,11)}$. However, wheat gluten (WG) was also found to be hypocholesterolaemic compared to $\mathrm{CAS}^{(12,13)}$. When more than two dietary groups were included, the limiting amino acid was added to the investigated protein in an attempt to provide a mechanistic explanation for the observed effects. For example, the limiting amino acids lysine + threonine and methionine were added to WG and SOY, respectively, to elucidate their role in cholesterol and long-chain PUFA metabolism ${ }^{(14,15)}$.

In addition, it is imperative to use an animal model whose lipid metabolism in response to dietary nutrients closely mimics that of man. The hamster, in opposition to the rat, is a valid model for this purpose ${ }^{(16)}$, especially in light of the high content of fat in human diets in comparison with commonly used rodent diets (see Materials and methods section and Table 1). Last but not least, because lipid metabolism is primarily determined by the amount and type of dietary fats, it is important to investigate the effect of protein source under conditions that reflect habitual fat intakes, in this case under fatty acid intakes that are representative of the Canadian diet ${ }^{(17)}$ (see Materials and methods section and Table 2). However, dietary cholesterol was not added to the diets in the present study because it strongly impacts

Abbreviations: BF, beef protein; CAS, casein; CYP7A1, cholesterol $7 \alpha$-hydroxylase; HMG-CoAr, 3-hydroxy-3-methylglutaryl-CoA reductase;

HDL-C, HDL-cholesterol; LDL-C, LDL-cholesterol; LDL-R, LDL receptor; PL, phospholipids; SOY, soya protein; SR-B1, scavenger receptor B1; TC, total

cholesterol; WG, wheat gluten.

* Corresponding author: Dr W. M. Nimal Ratnayake, fax +1 613941 6182, email nimal_ratnayake@hc-sc.gc.ca 
Table 1. Composition of the experimental diets ( $\mathrm{g} / \mathrm{kg})$

\begin{tabular}{|c|c|c|c|c|}
\hline Ingredient & $\mathrm{CAS}^{*}$ & $\mathrm{BF} \dagger$ & WG $\neq$ & $\mathrm{SOY}^{*}$ \\
\hline Protein§ & 222 & 222 & 264 & 222 \\
\hline Cornstarch $\ddagger$ & 273 & 273 & 231 & 273 \\
\hline Sucrose\| & 136 & 136 & 136 & 136 \\
\hline Fat blend & 155 & 155 & 155 & 155 \\
\hline Cellulose* & 100 & 100 & 100 & 100 \\
\hline Wheat bran* & 50 & 50 & 50 & 50 \\
\hline Hayes Mineral Mix ${ }^{\star}$ & 46 & 46 & 46 & 46 \\
\hline Hayes Cathcart Vitamin Mix ${ }^{*}$ & 12 & 12 & 12 & 12 \\
\hline Choline dihydrogen citrate* & 6 & 6 & 6 & 6 \\
\hline Total & 1000 & 1000 & 1000 & 1000 \\
\hline Metabolizable energy $(\mathrm{kJ} / \mathrm{g})^{\star \star}$ & $16 \cdot 49$ & $16 \cdot 49$ & $16 \cdot 49$ & $16 \cdot 74$ \\
\hline
\end{tabular}

$\mathrm{BF}$, beef protein; CAS, casein; SOY, soya protein; WG, wheat gluten.

* Harlan Teklad (Madison, WI, USA): vitamin-free CAS and isolated SOY.

†Extra lean ground beef (local butcher, Gatineau, QC, Canada), defatted and freeze-dried.

$\ddagger$ Dyets Inc. (Bethlehem, PA, USA).

$\S$ Provided as $20 \%(\mathrm{~W} / \mathrm{w})$ actual protein content, as per manufacturer's powder composition sheet for CAS, WG and SOY, and based on nitrogen content of BF by micro-Kjeldahl method.

\|l Lantic Ltd (Montreal, QC, Canada).

ๆ Consisting of low-erucid acid rapeseed oil (50\%), coconut oil (28\%), lard (12\%), soyabean oil $(5 \%)$, butter $(5 \%)$ and flaxseed oil $(1 \%)$.

** Energy was calculated by adding the energy contributed from protein (CAS and $\mathrm{BF}=15.07 \mathrm{~kJ} / \mathrm{g} ; \mathrm{WG}=15.36 \mathrm{~kJ} / \mathrm{g} ; \mathrm{SOY}=16.24 \mathrm{~kJ} / \mathrm{g}$ ), carbohydrate (starch and sucrose $=16.74 \mathrm{~kJ} / \mathrm{g}$ ), fat (fat blend $=37.68 \mathrm{~kJ} / \mathrm{g})$ and wheat bran $(9.40 \mathrm{~kJ} / \mathrm{g})$.

hepatic cholesterol and LDL-C metabolism in a dose-dependent manner in the hamster ${ }^{(18)}$, but not in $\operatorname{man}^{(19)}$; and because it modulates the expression of genes and/or activity of enzymes involved in lipid metabolism ${ }^{(20)}$ to an extent that might mask the effect of dietary protein on such indices. Although humans consume protein from different sources and the impact of diet on lipid metabolism is modulated by several nutrients, elucidating the effects of individual nutritional factors, in this case protein, will help develop dietary strategies aiming at optimizing or improving cardiovascular health.

Therefore, the objective of the present study was to compare systematically the effect of four different un-supplemented proteins of both animal and vegetable sources on

Table 2. Fatty acid (FA) composition of the experimental diets (\% of total FA)*

\begin{tabular}{|c|c|c|c|c|c|}
\hline Fatty acid & Fat blend $\dagger$ & CAS & BF & WG & SOY \\
\hline $10: 0$ & $1 \cdot 3$ & 1.4 & $1 \cdot 3$ & $1 \cdot 1$ & 1.4 \\
\hline $12: 0$ & $12 \cdot 2$ & $12 \cdot 2$ & 11.9 & $10 \cdot 9$ & $11 \cdot 8$ \\
\hline $14: 0$ & $5 \cdot 8$ & $5 \cdot 7$ & $5 \cdot 6$ & $5 \cdot 3$ & $5 \cdot 4$ \\
\hline $16: 0$ & 9.8 & $9 \cdot 9$ & $10 \cdot 1$ & $10 \cdot 8$ & $10 \cdot 2$ \\
\hline $18: 0$ & 4.4 & 4.4 & 4.6 & $4 \cdot 2$ & 4.4 \\
\hline Total SFA & $35 \cdot 0$ & $35 \cdot 1$ & 34.9 & 33.4 & $35 \cdot 2$ \\
\hline $18: 1 n-9$ & $37 \cdot 6$ & $37 \cdot 0$ & $36 \cdot 8$ & 34.9 & $35 \cdot 8$ \\
\hline Total MUFA & $41 \cdot 8$ & $41 \cdot 1$ & $41 \cdot 0$ & $38 \cdot 8$ & $39 \cdot 8$ \\
\hline $18: 2 n-6$ & $16 \cdot 1$ & $16 \cdot 7$ & $16 \cdot 7$ & 20.8 & $18 \cdot 0$ \\
\hline $20: 4 n-6$ & 0.0 & 0.0 & 0.1 & 0.0 & 0.0 \\
\hline Total $n-6$ PUFA & $16 \cdot 3$ & $16 \cdot 9$ & $17 \cdot 2$ & $21 \cdot 0$ & $18 \cdot 1$ \\
\hline $18: 3 n-3$ & $6 \cdot 1$ & $6 \cdot 0$ & $5 \cdot 8$ & 5.9 & $6 \cdot 0$ \\
\hline $20: 5 n-3$ & 0.0 & 0.0 & 0.0 & 0.0 & 0.0 \\
\hline $22: 6 n-3$ & 0.0 & 0.0 & 0.0 & 0.0 & 0.0 \\
\hline Total $n-3$ PUFA & $6 \cdot 1$ & $6 \cdot 1$ & $6 \cdot 1$ & $6 \cdot 2$ & $6 \cdot 2$ \\
\hline $18: 2 n-6 / 18: 3 n-3$ & $2 \cdot 7$ & $2 \cdot 8$ & 2.9 & 3.5 & 3 \\
\hline Total trans FA & 0.8 & 0.8 & 0.8 & 0.7 & 0.8 \\
\hline
\end{tabular}

$\mathrm{BF}$, beef protein; CAS, casein; SOY, soya protein; WG, wheat gluten.

* See Materials and methods section for details of lipid extraction and analysis.

†Fat blend consisted of low-erucid acid rapeseed oil $(50 \%)$, coconut oil $(28 \%)$, lard $(12 \%)$, soyabean oil $(5 \%)$, butter $(5 \%)$ and flaxseed oil $(1 \%)$. plasma lipids, long-chain fatty acid metabolism in the liver, and expression of genes involved in hepatic lipid metabolism in hamsters fed cholesterol-free diets.

\section{Materials and methods}

\section{Animals and diets}

The Health Canada Animal Care Committee approved the animal experimental protocol, and maintenance of the animals followed the guidelines of the Canadian Council for Animal Care. Male golden Syrian hamsters ( $n$ 28; age 30-33d) were purchased from Charles River (St-Constant, QC, Canada). Upon arrival, they were housed individually in ventilated plastic transparent cages with bedding in a climate-controlled environment maintained at a temperature of $22 \pm 1{ }^{\circ} \mathrm{C}$ and $60 \%$ relative humidity with a $12: 12 \mathrm{~h}$ light-dark cycle. After a week of acclimation during which a commercial rodent feed (Purina chow \# 5001) was provided, the hamsters (seven per group; average body weight $84 \mathrm{~g}$ ) were given free access to one of the four experimental diets : CAS, beef protein (BF), WG and SOY (Table 1). The diets were formulated based on a modification of the Hayes Purified Diet for Hamsters $^{(21)}$. Dietary protein accounted for $20 \%(\mathrm{w} / \mathrm{w})$ based on pure protein content (as per manufacturer's sheet composition for CAS, WG and SOY, and based on nitrogen content of BF by micro-Kjeldahl method). Extra lean ground beef was purchased from a local butcher (Gatineau, QC, Canada), defatted, freeze-dried and pulverized into a powdered form before mixing it with other ingredients in the diet.

Dietary fat accounted for $15.5 \%(\mathrm{w} / \mathrm{w})$ of the total diet (Table 1) and consisted of a blend of rapeseed oil (50\%), coconut oil $(28 \%)$, lard $(12 \%)$, soyabean oil $(5 \%)$, butter (5\%) and flaxseed oil (1\%). This fat blend was chosen to provide SFA, MUFA and PUFA at levels similar to those estimated for the average Canadian diet ${ }^{(17)}$. Lard and butter did not contribute significantly to the cholesterol content of the diet (approximately $0.003 \%$ ). Total nitrogen in proteins and diets was determined (in duplicate) by the micro-Kjeldahl method using a Kjeltec Auto 2400 Analyser (Höganäs, Sweden). Protein was calculated using a nitrogen-to-protein ratio factor of 6.25. Diets were hydrolysed (in duplicate) with $6 \mathrm{M}-\mathrm{HCl}$ at $110^{\circ} \mathrm{C}$ for $22 \mathrm{~h}$ for the determination of total amino acids except sulphur amino acids and tryptophan ${ }^{(22)}$. Hydrolysates for the determination of methionine as methionine sulphone and cyste(i)ne as cysteic acid were prepared by performic acid oxidation of protein followed by hydrolysis with $6 \mathrm{M}-\mathrm{HCl}^{(22)}$. All amino acids, except tryptophan, in hydrolysates were determined by liquid chromatography of precolumn phenylisothiocyanate derivatives ${ }^{(23)}$ using Waters 600 Controller with Waters 717plus Autosampler and Waters 996 Photoiode Array Detector $(254 \mathrm{~nm}$; Waters, Milford, MA, USA) (Table 3). The fatty acid composition of the diet (Table 2) was determined as described later.

\section{Procedures}

Fresh food was provided and measurements of food intake and body weight were taken twice a week. On these same days, cages were changed and fresh bedding was provided, spiked with a small amount of the old bedding from the same cage to 
Table 3. Amino acid composition of the experimental diets ( $\mathrm{g} / 100 \mathrm{~g}$ protein)*

\begin{tabular}{|c|c|c|c|c|}
\hline Amino acid & CAS & BF & WG & SOY \\
\hline Alanine & $3 \cdot 1$ & $5 \cdot 0$ & $2 \cdot 5$ & 3.9 \\
\hline Arginine & $4 \cdot 1$ & 6.0 & 3.7 & $7 \cdot 3$ \\
\hline Aspartic acid & $6 \cdot 6$ & $7 \cdot 8$ & 2.9 & 9.9 \\
\hline Cystine & 0.7 & 1.4 & $2 \cdot 2$ & 1.7 \\
\hline Glutamic acid & $22 \cdot 4$ & $14 \cdot 3$ & 34.4 & $18 \cdot 4$ \\
\hline Glycine & $2 \cdot 2$ & $4 \cdot 3$ & 3.4 & 4 \\
\hline Histidine & $3 \cdot 2$ & 3.7 & $2 \cdot 4$ & $2 \cdot 8$ \\
\hline Isoleucine & $5 \cdot 8$ & 4.6 & $4 \cdot 1$ & $4 \cdot 8$ \\
\hline Leucine & $9 \cdot 7$ & $7 \cdot 7$ & $6 \cdot 8$ & $7 \cdot 7$ \\
\hline Lysine & $7 \cdot 6$ & $7 \cdot 8$ & $2 \cdot 0$ & 5.9 \\
\hline Methionine & $3 \cdot 1$ & $2 \cdot 6$ & 1.4 & $1 \cdot 2$ \\
\hline Phenylalanine & $5 \cdot 4$ & 4.0 & $5 \cdot 0$ & $5 \cdot 2$ \\
\hline Proline & $10 \cdot 8$ & $3 \cdot 8$ & 11.9 & 5 \\
\hline Serine & $6 \cdot 4$ & $4 \cdot 3$ & $5 \cdot 4$ & $5 \cdot 7$ \\
\hline Threonine & $4 \cdot 6$ & 4.4 & $2 \cdot 8$ & 3.9 \\
\hline Tyrosine & $5 \cdot 6$ & $3 \cdot 3$ & 3.4 & $3 \cdot 8$ \\
\hline Valine & $6 \cdot 7$ & $4 \cdot 8$ & 3.9 & $4 \cdot 7$ \\
\hline
\end{tabular}

BF, beef protein; CAS, casein; SOY, soya protein; WG, wheat gluten

${ }^{*}$ Amino acid composition of the diets was determined according to the method developed by Sarwar et al. ${ }^{(23)}$.

minimize variation in the surroundings. Hamsters had unlimited access to food and water during the entire experimental phase. At the end of the eighth week, the animals were fasted for at least $16 \mathrm{~h}$ prior to killing by exsanguination through cardiac puncture under general anaesthesia with isoflurane. Blood was collected in serum separator tubes gel and clot activator tubes and centrifuged at $1000 \mathrm{~g}$ for $10 \mathrm{~min}$ at $4^{\circ} \mathrm{C}$ to obtain serum for the analysis of lipids. The liver was removed and immediately frozen in liquid nitrogen and stored at $-80^{\circ} \mathrm{C}$ until analysis.

\section{Serum lipids}

Serum TAG, TC and HDL-C were measured using a microplate enzymatic colorimetric method (Randox Laboratories, Mississauga, ON, Canada; catalogue numbers TR 201, CH 201 and $\mathrm{CH} 204$, respectively) according to the manufacturer's instructions. Non-HDL-C was determined by subtracting HDL-C from TC.

\section{Fatty acid composition of diets and liver phospholipids}

Total lipids were extracted from diets and livers with chloroform-methanol-water $(2: 2: 1 \cdot 8 \text {, by vol. })^{(24)}$. Phospholipids (PL) from liver total lipids were separated and isolated by TLC with development in hexane-diethyl ether-acetic acid (85:15:1, by vol.). Lipids from the diets and liver PL were then transmethylated with $0.5 \mathrm{M}$-methanolic $\mathrm{HCl}$. The fatty acid methyl esters were analysed by GC with a flame ionization decay detector and auto-sampler (Agilent Technologies 6890 N) using a Supelcowax-10 flexible fused silica capillary column $(30 \mathrm{~m} \times 0.25 \mathrm{~mm} \times 0.25 \mu \mathrm{m}$, Supelco Inc., Bellefonte, PA, USA). The fatty acids were identified by comparing their retention times with those of a standard mixture of fatty acid methyl esters (Supelco 37 FAME catalogue number 47 885-U; Supelco Inc.). The fatty acids were expressed as $\%$ of total fatty acids.

\section{Quantitation of mRNA abundances of selected hepatic enzymes and receptors involved in lipid metabolism}

Total RNA was isolated from hamster liver samples with TRIzol reagent (Invitrogen Canada Inc., Burlington, ON, Canada) according to the manufacturer's instructions. Total RNA (500 ng) was reverse transcribed with M-MLV RT (Invitrogen Canada Inc.) for cDNA synthesis. One-tenth of the synthesized cDNA was then amplified using Taq DNA polymerase (New England Biolabs, Beverly, MA, USA) with the primers listed in Table 4 for the following genes: LDL-R, scavenger receptor B1 (SR-B1), also known as HDL receptor, cholesterol $7 \alpha$-hydroxylase (CYP7A1), 3-hydroxy-3-methylglutaryl-CoA reductase (HMG-CoAr), lecithin-cholesterol acyltransferase, $\Delta 6$-desaturase, $\Delta 5$-desaturase (Invitrogen Canada Inc.), and universal 18S rRNA primers and competimers (Ambion Inc., Austin, TX, USA). PCR conditions were $94^{\circ} \mathrm{C}$ for $5 \mathrm{~min}, 94^{\circ} \mathrm{C}$ for $30 \mathrm{~s}$, annealing temperature (Table 4), $72^{\circ} \mathrm{C}$ for $30 \mathrm{~s}$ and $72^{\circ} \mathrm{C}$ for $10 \mathrm{~min}$. The annealing temperatures, ratios of $18 \mathrm{~S}$ rRNA primer-competimer and amplification cycle numbers for each gene were optimized to ensure that the amplifications were in the linear range. Samples were resolved on pre-cast $2 \%$ agarose gels in the

Table 4. Oligonucleotide sequence for reverse transcription and RT-PCR

\begin{tabular}{|c|c|c|c|c|c|c|c|}
\hline Genes & Species & Accession no. & Primer sequence* $^{*}$ & $\begin{array}{l}\text { Length } \\
\text { (bp) }\end{array}$ & $\begin{array}{l}\text { Temp. } \\
\left({ }^{\circ} \mathrm{C}\right)\end{array}$ & Cycles & 18S $\mathrm{P}: \mathrm{C}$ ratio \\
\hline LDL-R & Cricetulus griseus & M94387 & $\begin{array}{l}\text { Forward: 5'-TGGCTACGAGTGCTTGTGTC-3' } \\
\text { Reverse: 5'-ATCCCCACTGATGATGGTGT-3' }\end{array}$ & 411 & 60 & 31 & $2: 8$ \\
\hline SR-B1 & Cricetulus griseus & U11453 & $\begin{array}{l}\text { Forward: 5'-TGCAGACCCTGTGCTATCAG-3' } \\
\text { Reverse: 5'-TGAATGGCCTCCTTATCCTG-3' }\end{array}$ & 416 & 60 & 30 & $2: 8$ \\
\hline CYP7A1 & Rattus rattus & X17595 & $\begin{array}{l}\text { Forward: 5'-CTGCAAACTGATGGGAAAT-3' } \\
\text { Reverse: 5'-TGCATCATGGCTTCAGAAAG-3' }\end{array}$ & 236 & 60 & 33 & $2: 8$ \\
\hline LCAT & Rattus norvegicus & U62803 & $\begin{array}{l}\text { Forward: 5'-CTGTTGCTGTTGGGGCTACT-3' } \\
\text { Reverse: 5'-TTGAAATCCAGCCAGATGGT-3' }\end{array}$ & 232 & 60 & 30 & $2: 8$ \\
\hline$\Delta 6 \mathrm{D}$ & Rattus norvegicus & AB021980 & $\begin{array}{l}\text { Forward: 5'-AAGGGAGGTAACCAGGGAGA-3' } \\
\text { Reverse: 5'-ATGATGTGGGACAGGAGGAG-3' }\end{array}$ & 415 & 58 & 30 & $3: 7$ \\
\hline$\Delta 5 \mathrm{D}$ & Rattus norvegicus & AF320509 & $\begin{array}{l}\text { Forward: 5'-GAGCAGTCCAGCTTTGAACC-3' } \\
\text { Reverse: 5'-TGGTTGTATGGCATGTGCTT-3' }\end{array}$ & 496 & 60 & 28 & $4: 6$ \\
\hline
\end{tabular}

CYP7A1, cholesterol $7 \alpha$-hydroxylase; $\Delta 5 \mathrm{D}, \Delta 5$-desaturase; $\Delta 6 \mathrm{D}, \Delta 6$-desaturase; HMG-CoAr, 3-hydroxy-3-methylglutaryl-CoA reductase; LCAT, lecithin-cholesterol acyltransferase; LDL-R, LDL receptor; P:C, primer:competimer; SR-B1, scavenger receptor B1; Temp., annealing temperature.

${ }^{*}$ All primers listed in the table were purchased from Invitrogen Canada Inc. (Burlington, ON, Canada). 
presence if ethidium bromide (Invitrogen Canada Inc.). Multiple images of each gel were taken with different exposure time using the BioDoc-It Imaging System (UVP Inc., Upland, CA, USA). Densities of the appropriate images were measured using the Scion Image software, and mRNA abundances of each gene were normalized against their respective 18S rRNA content, which was not affected by our treatments (data not shown).

\section{Statistical analysis}

Data were analysed by one-way ANOVA. If significance was observed $(P \leq 0 \cdot 05)$, Duncan's multiple range test was used to identify differences in the effect of individual diets. This post hoc test was used instead of the more rigid Tukey's honest significant differences because of the relatively small sample size and the large variability within dietary groups. Statistica 7 for Windows 2000 (StatSoft, Tulsa, OK, USA) was used in all analyses. All data are expressed as means and their standard errors.

\section{Results}

\section{Food intake and body weight}

There were no significant differences in average food intake per day $(P=0 \cdot 14)$, body weight at the end of the study $(P=0.94)$ and body weight gain $(P=0.94)$ of hamsters during the feeding phase among the four dietary protein groups (Table 5).

\section{Serum lipids}

Protein source had a significant effect on serum TC $(P=0.0086)$, HDL-C $(P=0.027)$ and non-HDL-C $(P=0.049)$, but not on TAG $(P=0.065)$ (Table 5). Hamsters fed WG had significantly lower serum TC and HDL-C than hamsters fed either BF or SOY. Hamsters fed CAS also had significantly lower HDL-C than those fed BF or SOY, but significantly lower TC than only BF. However, only hamsters fed WG had significantly lower non-HDL-C than those fed BF. A trend to lower TAG concentrations was observed in the animals fed WG and SOY compared to BF, but this was not significant $(P=0 \cdot 065)$.

\section{Fatty acid composition of liver phospholipids}

Protein source had a significant effect on the relative level (\% of total) of several fatty acids in liver PL, including $18: 3 n-3$ $(P=0.0011), \quad 20: 5 n-3 \quad(P=0.0045), 22: 5 n-3 \quad(P=0 \cdot 0001)$, $22: 6 n-3(P=0 \cdot 0007)$, total $n-3$ PUFA $(P=0 \cdot 0013), 20: 4 n-6$ $(P=0 \cdot 0000), 18: 3 n-6(P=0 \cdot 04), 20: 3 n-6(P=0 \cdot 0013)$, total $n$-6 PUFA $(P=0.0005), 18: 1 n-9(P=0.0002)$, total MUFA $(P=0.0001)$, as well as $20: 5 n-3 / 18: 3 n-3(P=0 \cdot 0089)$ and $22: 6 n-3 / 18: 3 n-3$ ratios $(P=0 \cdot 0001)$, but not on $18: 2 n-6$ $(P=0 \cdot 56), 16: 0 \quad(P=0 \cdot 27), 18: 0 \quad(P=0 \cdot 17)$ or total SFA $(P=0.08)$ (Table 6).

For the $n$-3 PUFA series, hamsters fed WG or SOY had significantly lower percentages of $18: 3 n-3$ and $22: 5 n-3$, but significantly higher percentages of $22: 6 n-3$, total $n-3$ PUFA, as well as ratio of $20: 5 n-3 / 18: 3 n-3$ and $22: 6 n-3 / 18: 3 n-3$ than hamsters fed BF. However, only hamsters fed WG or BF had significantly lower percentages of $20: 5 n-3$ than those fed CAS. In addition, hamsters fed CAS had percentage of $22: 5 n-3$ significantly lower than those fed BF, but higher than those fed WG or SOY, and a significantly lower ratio of $20: 5 n-3 / 18: 3 n-3$ than hamsters fed SOY.

For the $n-6$ PUFA series, hamsters fed WG, SOY or CAS had significantly lower percentages of $20: 4 n-6$ and total $n$-6 PUFA than those fed BF. However, hamsters fed WG or SOY had significantly lower $20: 3 n-6$ than those fed either BF or CAS. On the other hand, hamsters fed WG had significantly higher percentages of $18: 3 n-6$ than those fed BF or CAS.

For the MUFA, hamsters fed WG or SOY had significantly lower percentages of $18: 1 n-9$ and total MUFA than those fed $\mathrm{BF}$ or CAS.

mRNA abundances of selected hepatic enzymes and receptors involved in lipid metabolism

Protein source had a significant effect on the mRNA abundances of CYP7A1 $(P=0.052)$, LDL-R $(P<0.0049)$ and $\Delta 6$-desaturase $(P<0.032)$, but not those of HMG-CoAr $(P=0 \cdot 21)$, lecithin-cholesterol acyltransferase $(P=0 \cdot 49)$, SRB1 $(P=0 \cdot 15)$ or $\Delta 5$-desaturase $(P=0 \cdot 74)$ (Fig. 1$)$.

With respect to the selected enzymes and receptors involved in cholesterol and lipoprotein metabolism, hamsters fed WG or SOY had significantly higher mRNA abundances (ratio to

Table 5. Food intake, body weight and plasma lipid concentrations of hamsters fed one of the four different sources of protein in their diets for 8 weeks

(Mean values with their standard errors for seven hamsters per group)

\begin{tabular}{|c|c|c|c|c|c|c|c|c|c|}
\hline & \multicolumn{2}{|c|}{ CAS } & \multicolumn{2}{|c|}{ BF } & \multicolumn{2}{|c|}{ WG } & \multicolumn{2}{|c|}{ SOY } & \multirow[b]{2}{*}{$P$} \\
\hline & Mean & SEM & Mean & SEM & Mean & SEM & Mean & SEM & \\
\hline Food intake $(\mathrm{g})^{\star}$ & $6 \cdot 1$ & 0.17 & $6 \cdot 7$ & 0.27 & $6 \cdot 3$ & 0.11 & $6 \cdot 2$ & 0.22 & 0.14 \\
\hline Body weight (g)† & 128.9 & 3.93 & $131 \cdot 2$ & 4.20 & $132 \cdot 1$ & 2.99 & $131 \cdot 3$ & 4.52 & 0.94 \\
\hline Body weight gain (g) & $45 \cdot 6$ & 4.41 & $45 \cdot 5$ & 3.96 & $48 \cdot 3$ & 2.92 & 46.9 & 3.55 & 0.94 \\
\hline \multicolumn{10}{|l|}{ Serum lipids (mmol/l) } \\
\hline TAG & 1.0 & 0.13 & 1.3 & 0.18 & 0.9 & 0.09 & 0.8 & 0.08 & 0.065 \\
\hline TC & $2 \cdot 5^{\mathrm{bc}}$ & 0.19 & $3 \cdot 4^{\mathrm{a}}$ & 0.36 & $2 \cdot 3^{\mathrm{C}}$ & 0.08 & $3.0^{\mathrm{ab}}$ & 0.13 & 0.0086 \\
\hline HDL-C & $1.9^{\mathrm{b}}$ & 0.14 & $2 \cdot 3^{a}$ & 0.16 & $1.8^{\mathrm{b}}$ & 0.10 & $2 \cdot 3^{a}$ & 0.14 & 0.027 \\
\hline Non-HDL-C & $0.6^{\mathrm{ab}}$ & 0.07 & $1.1^{\mathrm{a}}$ & 0.25 & $0.5^{\mathrm{b}}$ & 0.06 & $0.7^{\mathrm{ab}}$ & 0.10 & 0.049 \\
\hline
\end{tabular}

BF, beef protein; CAS, casein; HDL-C, HDL-cholesterol; SOY, soya protein; TC, total cholesterol; WG, wheat gluten.

a,b,c Mean values within a row with unlike superscript letters were significantly different $(P<0.05)$.

${ }^{*}$ Food intake is the average intake per day over 8 weeks.

†Body weight at the end of the 8-week feeding period. 
Table 6. Fatty acid (FA) profile of liver phospholipids of hamsters fed one of the four different sources of protein in their diets for 8 weeks

(Mean values with their standard errors for six hamsters per group)

\begin{tabular}{|c|c|c|c|c|c|c|c|c|c|}
\hline \multirow[b]{2}{*}{ FA } & \multicolumn{2}{|c|}{ CAS } & \multicolumn{2}{|c|}{ BF } & \multicolumn{2}{|c|}{ WG } & \multicolumn{2}{|c|}{ SOY } & \multirow[b]{2}{*}{$P$} \\
\hline & Mean & SEM & Mean & SEM & Mean & SEM & Mean & SEM & \\
\hline \multicolumn{10}{|l|}{$\%$ of total FA } \\
\hline $16: 0$ & $17 \cdot 5$ & 0.20 & $17 \cdot 3$ & 0.42 & $17 \cdot 1$ & 0.42 & $18 \cdot 1$ & 0.48 & 0.27 \\
\hline $18: 0$ & $19 \cdot 8$ & 0.54 & $20 \cdot 2$ & 0.36 & $21 \cdot 3$ & 0.51 & 20.9 & 0.57 & 0.17 \\
\hline Total SFA & 38.9 & 0.64 & 38.9 & 0.28 & 39.9 & 0.31 & $40 \cdot 6$ & 0.67 & 0.08 \\
\hline $18: 1 n-9$ & $8 \cdot 5^{\mathrm{a}}$ & 0.47 & $8 \cdot 5^{\mathrm{a}}$ & 0.19 & $6 \cdot 5^{\mathrm{b}}$ & 0.18 & $7 \cdot 1^{b}$ & 0.27 & 0.0002 \\
\hline Total MUFA & $10 \cdot 8^{a}$ & 0.58 & $10 \cdot 8^{a}$ & 0.20 & $8 \cdot 3^{b}$ & 0.18 & $9 \cdot 1^{\mathrm{b}}$ & 0.28 & 0.0001 \\
\hline $18: 2 n-6$ & $15 \cdot 8$ & 0.51 & $15 \cdot 8$ & 0.35 & $15 \cdot 3$ & 0.21 & $15 \cdot 1$ & 0.55 & 0.56 \\
\hline $18: 3 n-6$ & $0.49^{b}$ & 0.02 & $0.47^{\mathrm{b}}$ & 0.04 & $0.61^{a}$ & 0.05 & $0.59^{a}$ & 0.04 & 0.04 \\
\hline $20: 3 n-6$ & $1 \cdot 1^{a}$ & 0.07 & $1 \cdot 1^{\mathrm{a}}$ & 0.08 & $0.81^{b}$ & 0.04 & $0.87^{b}$ & 0.03 & 0.0013 \\
\hline $20: 4 n-6$ & $13 \cdot 9^{b}$ & 0.30 & $15 \cdot 9^{a}$ & 0.22 & $14 \cdot 5^{\mathrm{b}}$ & 0.25 & $14 \cdot 0^{\mathrm{b}}$ & 0.14 & 0.0000 \\
\hline Total $n-6$ PUFA & $32 \cdot 2^{b}$ & 0.32 & $34 \cdot 4^{a}$ & 0.54 & $32 \cdot 2^{\mathrm{b}}$ & 0.17 & $31 \cdot 5^{\mathrm{b}}$ & 0.54 & 0.0005 \\
\hline $18: 3 n-3$ & $0.21^{a}$ & 0.02 & $0 \cdot 19^{a}$ & 0.01 & $0.15^{\mathrm{b}}$ & 0.01 & $0.15^{\mathrm{b}}$ & 0.02 & 0.0011 \\
\hline $20: 5 n-3$ & $0.43^{\mathrm{a}}$ & 0.02 & $0.36^{a}$ & 0.01 & $0.35^{\mathrm{a}}$ & 0.01 & $0.40^{\mathrm{ab}}$ & 0.01 & 0.0045 \\
\hline $22: 5 n-3$ & $0.56^{\mathrm{b}}$ & 0.02 & $0.64^{a}$ & 0.02 & $0.49^{c}$ & 0.02 & $0.47^{c}$ & 0.02 & 0.0001 \\
\hline $22: 6 n-3$ & $16 \cdot 2^{\mathrm{a}}$ & 0.62 & $14 \cdot 0^{\mathrm{b}}$ & 0.53 & $18 \cdot 0^{a}$ & 0.31 & $17 \cdot 1^{\mathrm{a}}$ & 0.78 & 0.0007 \\
\hline Total $n-3$ PUFA & $18 \cdot 0^{\mathrm{a}}$ & 0.61 & $15 \cdot 8^{b}$ & 0.51 & $19 \cdot 5^{\mathrm{a}}$ & 0.31 & $18 \cdot 8^{a}$ & 0.79 & 0.0013 \\
\hline \multicolumn{10}{|l|}{ Ratio } \\
\hline $20: 5 n-3 / 18: 3 n-3$ & $2 \cdot 2^{\mathrm{bc}}$ & 0.20 & $1.9^{c}$ & 0.09 & $2 \cdot 4^{\mathrm{ab}}$ & 0.14 & $2 \cdot 6^{a}$ & 0.13 & 0.0089 \\
\hline $22: 6 n-3 / 18: 3 n-3$ & $80 \cdot 8^{\mathrm{b}}$ & 6.99 & $73 \cdot 7^{b}$ & 4.41 & $124 \cdot 6^{\mathrm{a}}$ & 8.59 & $114 \cdot 5^{\mathrm{a}}$ & $6 \cdot 66$ & 0.0001 \\
\hline $22: 6 n-3 / 20: 5 n-3$ & $38 \cdot 0^{b}$ & $2 \cdot 77$ & $39 \cdot 5^{b}$ & $2 \cdot 28$ & $51 \cdot 9^{\mathrm{a}}$ & 1.02 & $43 \cdot 2^{b}$ & 1.02 & 0.0003 \\
\hline $20: 4 n-6 / 18: 2 n-6$ & 0.88 & 0.04 & $1 \cdot 0$ & 0.02 & 0.94 & 0.03 & 0.93 & 0.04 & 0.11 \\
\hline
\end{tabular}

CAS, casein; BF, beef protein; WG, wheat gluten; SOY, soya protein.

a,b,c Mean values within a row with unlike superscript letters were significantly different $(P<0.05)$.

18S) of LDL-R (Fig. 1 (a)) and CYP7A1 (Fig. 1 (b)) than hamsters fed BF, whereas hamsters fed CAS had significantly higher mRNA abundances of only LDL-R compared to those fed BF.

With respect to key enzymes involved in desaturation of the essential fatty acids linoleic acid and $\alpha$-linolenic acid, hamsters fed WG or SOY had significantly higher mRNA abundances (ratio to $18 \mathrm{~S}$ ) of $\Delta 6$-desaturase than those fed BF (Fig. 1 (c)).

\section{Discussion}

The results of the present study support the hypothesis that the protein source is a determinant of the effects of the diet on lipid metabolism in the hamster. In addition, these effects appear to be attributed, at least in part, to changes in the mRNA levels of enzymes and receptors involved in cholesterol, lipoprotein and long-chain fatty acid metabolism.

The observations that neither food intake, nor body weight, nor body weight gain were different among the four protein sources (Table 5) are of particular importance. First, although WG is deficient in lysine (Table 3), there is no evidence that this was limiting at the level provided in the experimental diets, supporting previous findings that the importance of protein quality to meet the hamster's requirements is reduced by virtue of its forestomach microbial activity that ferments dietary protein ${ }^{(25)}$. Second, and most importantly, the observed differences in lipid metabolism indices can be attributed solely to the protein source.

Although the protein source in the diet had an impact on serum lipid concentrations in the present study, the differences were observed mainly between WG and BF protein, whereas the effects of SOY and CAS were intermediate. The present observations are inconsistent with previous studies showing hypocholesterolaemic actions of either WG or SOY compared to CAS. For example, Endo et al. ${ }^{(13)}$ reported that a $12 \% \mathrm{WG}$ diet fed to adult male Wistar rats resulted in significantly lower TC and HDL-C, concomitant with higher expression of HMG-CoAr, HMG-CoA synthase and CYP7A1 than one with $12 \%$ CAS. Although we also observed higher expression of CYP7A1 and a trend towards higher expression of HMGCoAr, the discrepancy in the effects on circulating cholesterol could be due to the fact that the basal rate of hepatic cholesterol synthesis is high in the rat, whereas it is very low in the male hamster ${ }^{(16)}$. Because the contribution of the liver to whole body cholesterol synthesis is higher in the rat than in the hamster, an up-regulation of the expression of genes involved in cholesterol metabolism would have a greater impact on circulating cholesterol levels in the former. To our knowledge, this is the first study to investigate the effect of WG on lipid metabolism in hamsters, and thus, direct comparisons cannot be made. It is important to note as well that the $n-6+n-3$ PUFA content of the WG diet was up to $4 \%$ higher than that of the other diets. Although the effect of PUFA on cholesterol metabolism is well established, we do not believe that they contributed to the observed effect as WG and CAS, which have the highest and lowest levels of PUFA, resulted in similar cholesterol concentrations (Table 5).

Unlike WG, the cholesterolaemic effects of SOY and CAS have been compared in male hamsters, but the results are conflicting. Some studies have reported reduction of total, VLDL + LDL-C and HDL-C ${ }^{(26-29)}$, whereas others ${ }^{(30)}$, like us, have not. Such differences might be explained by both the cholesterol content and fatty acid composition of the diet. In most of these studies, cholesterol at a minimum level of $0.01 \%$ was added to the diet. Because dietary cholesterol substantially elevates TC and LDL-C in hamsters, an effect of protein can be more clearly observed when 
(a)
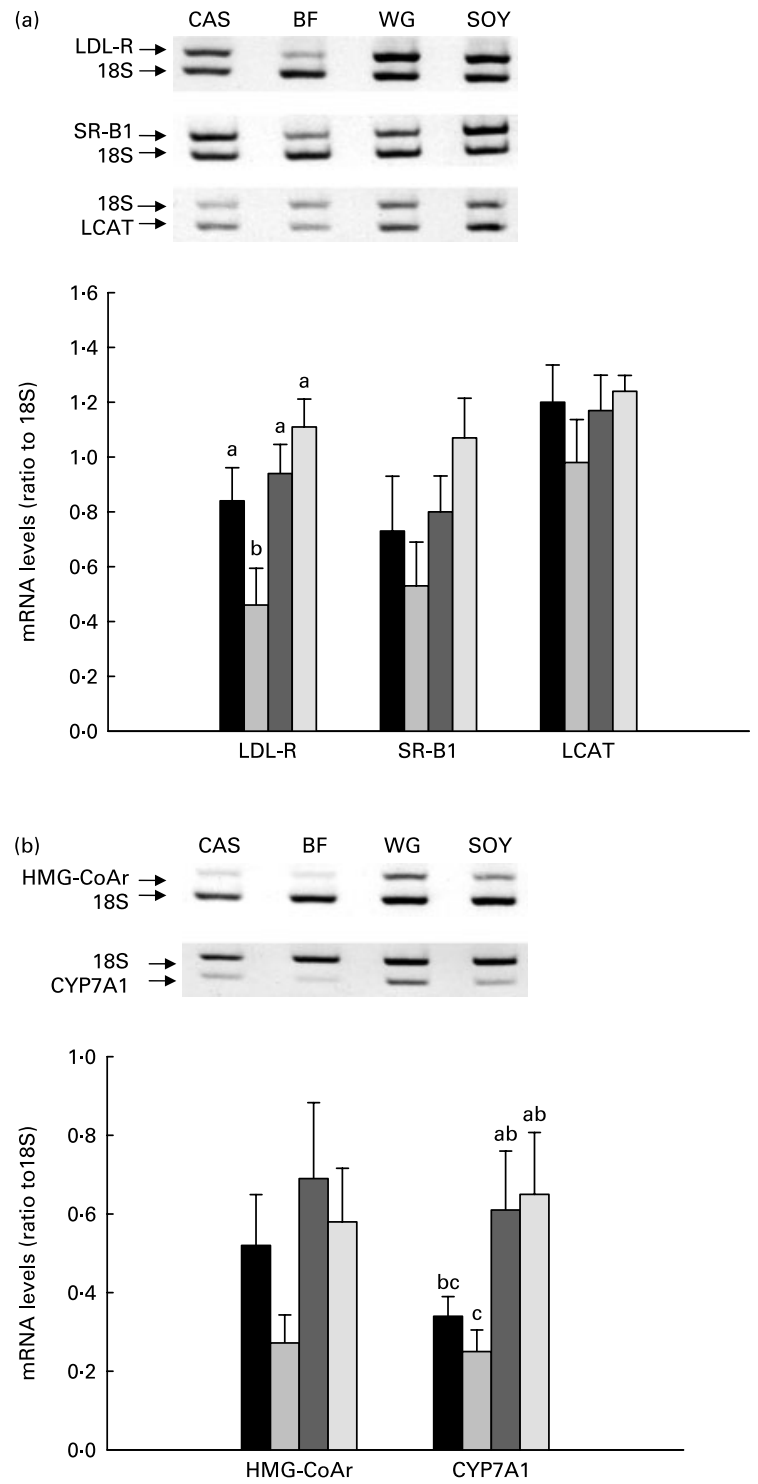

(c)
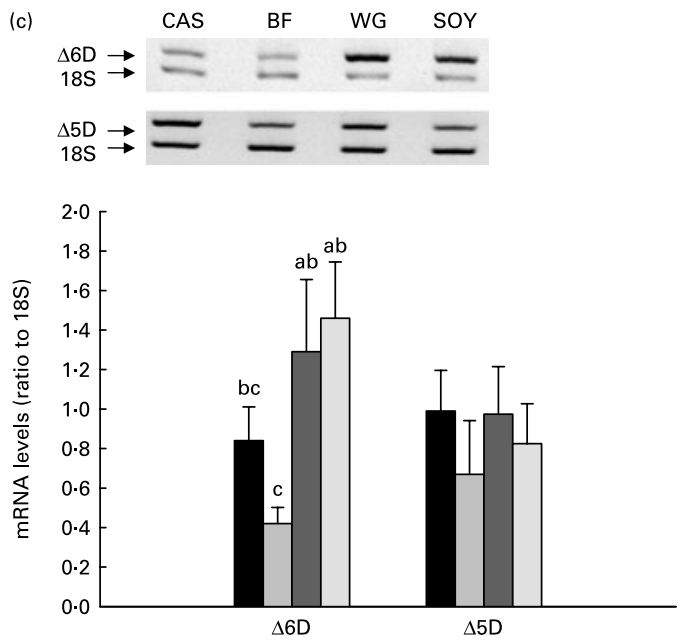

cholesterol is included in the diet. However, two groups also demonstrated a hypocholesterolaemic effect of SOY in hamsters fed cholesterol-free $\operatorname{diet}^{(27,31)}$. In these studies, the major source of fat was the SFA-rich coconut oil, which was shown to increase plasma LDL-C in hamsters in a diet essentially free of cholesterol, albeit the effect was less pronounced than in the presence of cholesterol ${ }^{(18)}$. Because the present diets were higher in unsaturated fatty acids than in SFA (ratio 1.7/1.0), it is possible that the hypocholesterolaemic effect of SOY (and WG) relative to CAS was obliterated in the absence of dietary cholesterol.

Of particular interest though was the observation that SOY resulted in higher HDL-C concentrations than either CAS or WG. Whereas it is not surprising that the hypocholesterolaemic effect of WG compared to SOY would affect HDL-C, the major carrier of plasma cholesterol in hamsters ${ }^{(32)}$, the higher HDL-C levels suggest a better lipoprotein profile in SOY-fed hamsters than CAS-fed ones. However, the present results cannot be explained by changes in SR-B1 or lecithincholesterol acyltransferase mRNA levels, which were similar among all dietary groups, albeit there was a trend for higher transcript levels in the SOY groups (Fig. 1 (a)). The SR-B1, commonly referred to as HDL receptor, selectively transports cholesterol esters from HDL particles to the liver ${ }^{(33)}$. Although such function results in lower circulating HDL-C, overexpression of SR-B1 has been shown to protect against CHD, whereas its absence leads to the opposite ${ }^{(34)}$. The anti-atherogenic effect of enhanced SR-B1 expression and/or activity despite decreased plasma HDL-C levels is indicative of enhanced reverse cholesterol transport, possibly due to negative hepatic cholesterol balance. Therefore, the higher concentrations of HDL-C in hamsters fed the SOY and BF diets could be due to alterations in the protein levels of these genes, in the expression and/or activity of other genes involved in HDL metabolism, such as Apo-AI or cholesteryl ester transfer protein, or simply to the fact that hamsters from both these diets had the highest levels of TC.

Perhaps the most important observation with respect to cholesterol metabolism was that $\mathrm{BF}$ protein resulted in the highest non-HDL-C (VLDL-cholesterol + LDL-C) that is accompanied by the highest and lowest expression of LDL$\mathrm{R}$ and CYP7A1, respectively. HMG-CoAr was also lowest in BF-fed hamsters, albeit not significantly. However, the absence of statistical significance should be interpreted with caution because fasting down-regulates the expression of sterol regulatory element binding proteins, which are transcription factors that control the transcription of a plethora of genes involved in lipid and lipoprotein metabolism, including HMG-CoAr and CYP7A1 ${ }^{(35)}$. Consequently, the

Fig. 1. Expression of genes involved in lipoprotein metabolism (a), hepatic cholesterol metabolism (b) and desaturation of $n-6$ and n-3 PUFA (c) in hamsters fed one of the four different sources of protein in their diets for 8 weeks (ם, CAS, casein; $\square$, BF, beef protein; $\square$, SOY, soya protein; $\square$, WG, wheat gluten). Values are means with their standard errors depicted by vertical bars (seven hamsters per group). ${ }^{a, b, c}$ Mean values within a cluster of bars with unlike superscript letters were significantly different by one-way ANOVA followed by Duncan's multiple range test $(P<0.05)$. CYP7A1, cholesterol 7 $\alpha$-hydroxylase; $\Delta 5 \mathrm{D}, \quad \Delta 5$-desaturase; $\Delta 6 \mathrm{D}, \quad \Delta 6$-desaturase; HMG-CoAr, 3-hydroxy-3-methylglutaryl-CoA reductase; LCAT, lecithin-cholesterol acyltransferase; LDL-R, LDL receptor; SR-B1, scavenger receptor B1. 
down-regulation of sterol regulatory element binding protein$1 \mathrm{c}$ by fasting would alleviate the inhibition of CYP7A1 gene expression. On the other hand, that of sterol regulatory element binding protein-2 would suppress the expression of HMG-CoAr, making it difficult to observe a significant effect of diet. Although it cannot be concluded that the changes in cholesterol metabolism are brought about by changes in the expression of the selected genes, the present results strongly suggest that protein source exerts its cholesterol-modulating effect at the level of the liver.

In addition to cholesterol, the present study provides further evidence that protein source affects long-chain PUFA metabolism. Specifically, WG, SOY and CAS resulted in higher relative concentrations of $22: 6 n-3$ and long-chain $n$-3 PUFA and lower concentrations of 20:4n-6, long-chain n-6 PUFA, 18: $1 n-9$ and total MUFA than BF in liver PL. However, only WG and SOY led to lower $18: 3 n-3$ levels and a higher $22: 6 n-3 / \alpha$-linolenic acid ratio than $\mathrm{BF}$, supporting previous findings that protein source impacts long-chain $n-6$ and $n-3$ PUFA metabolism ${ }^{(36,37)}$. Consistent with the present observations, WG- and SOY-fed hamsters had higher relative mRNA levels of $\Delta 6$-desaturase than those fed BF and CAS, although the difference was not significant with the latter. On the other hand, the relative abundance of $\Delta 5$-desaturase was similar in all groups despite lower levels of $20: 5 n-3$ in WGfed hamsters. This observation can be explained by enhanced elongation and desaturation of $20: 5 n-3$, as shown by higher ratios of $22: 6 n-3 / 20: 5 n-3$ and $22: 6 n-3 / 18: 3 n-3$.

The metabolic conversion of $\alpha$-linolenic acid to $20: 5 n-3$ and $22: 6 n-3$ has been the centre of much debate. Based on stable isotope tracer studies, it is estimated that only $8 \%$ of the $18: 3 n-3$ pool enters the desaturation/elongation pathway in man, and that its overall efficiency of conversion to $20: 5 n-3$ and $22: 6 n-3$ is $0 \cdot 2$ and $0 \cdot 05 \%$, respectively ${ }^{(38)}$. It is generally agreed that the $\Delta 6$ desaturation of $18: 3 n-3$ to $18: 4 n-3$ is the rate-limiting reaction within the long-chain $n-3$ PUFA cascade $^{(39)}$. Because $18: 2 n-6$ is also a substrate for $\Delta 6$-desaturase, the desaturation and elongation of $18: 3 n-3$ to $20: 5 n-3$ might be compromised at high intake ratios of $18: 2 n-6 / 18: 3 n-3$. The ratio of $18: 2 n-6 / 18: 3 n-3$ in our diets varied between 2.7 and $3 \cdot 5$, considered optimal for conversion of $18: 3 n-3$ to $20: 5 n-3$ and $22: 6 n-3^{(40)}$. Although we did not directly measure conversion, the $20: 5 n-3$ and $22: 6 n-3$ levels in liver PL of our hamsters mostly reflect desaturation and elongation of $18: 3 n-3$ because the test and adaptation period diets were devoid of both these fatty acids, and the tissue levels of 20:4n-6 and long-chain $n-6$ PUFA were lower in hamsters fed WG, SOY and CAS diets. Therefore, it is possible that hamsters have higher expression and activity of $\Delta 6$-desaturase than man and that the fatty acid profile of the diet enhanced the effect of protein on $22: 6 n-3$ levels in liver PL.

The finding that protein source impacts PUFA metabolism has important implications for cardiovascular health. Higher heart or erythocyte levels of $n-3$ PUFA have been associated with a lower risk for $\mathrm{CVD}^{(41)}$. This is partly due to the fact that they have anti-arrhythmic properties ${ }^{(42)}$ and are precursors of antiinflammatory and anti-aggregatory eicosanoids ${ }^{(43)}$. Although we measured fatty acid profile only in liver PL, it has been reported that entry into this compartment was a limiting factor for the conversion of $18: 3 n-3$ to $22: 6 n-3$, and that the hepatic conversion is a predictor of plasma PL composition ${ }^{(44,45)}$.
The exact mechanisms by which dietary protein affects lipid metabolism are not fully understood. The proteins provided in the diet are reported to have a high digestibility : $94 \%$ (WG and $\mathrm{BF}), 96 \%(\mathrm{SOY})$ and $99 \%(\mathrm{CAS})^{(46)}$, and it is unlikely that the small differences in digestibility account significantly to the observed results. Individual and/or groups of amino acids have been proposed to modulate cholesterol and fatty acid metabolism ${ }^{(47)}$. For example, dietary methionine content strongly and positively correlated with serum cholesterol levels ${ }^{(48)}$ and methionine supplementation abolished the hypocholesterolaemic effects of SOY in rats fed a cholesterol-free $\operatorname{diet}^{(49)}$. In addition, methionine increased $\Delta 6$-desaturase activity in rats ${ }^{(14)}$, and hepatic $\Delta 6$-desaturase activity appears to be regulated by $\Delta 6$-desaturase mRNA levels ${ }^{(50)}$. However, it is unlikely that the methionine content of our proteins explained the present results because CAS, which contains the highest amount of methionine (Table 3 ), had significantly lower concentrations of TC than BF, but similar ones to WG and SOY (Table 5), which contain the lowest amount (Table 3). Moreover, WG and/or SOY had the highest percentage of $22: 6 n-3$ in liver PL and hepatic $\Delta 6$-desaturase mRNA levels. In addition to methionine, cystine, lysine, glycine and arginine have been proposed to modulate cholesterol and PUFA metabolism, but the evidence is inconclusive and none of them appear to explain the present results.

The influence of bioactive peptides derived from protein digestion on lipid metabolism offers an alternative hypothesis. It has been increasingly acknowledged that the nutritional role of protein extends beyond the provision of amino acids for the synthesis of proteins. Bioactive peptides released during protein digestion can act locally (in the gut) or, if absorbed, in target organs to modulate a variety of physiological functions ${ }^{(51)}$. Bioactive peptides have been identified in many dietary proteins, including CAS, whey, $\mathrm{BF}, \mathrm{SOY}$ and $\mathrm{WG}^{(50)}$. Whether bioactive peptides play a role in modulating cholesterol and fatty acid metabolism, as we observed in the present study, is currently unknown. Some studies have shown that the hypocholesterolaemic effect of SOY is partly explained by the binding of undigested peptide fraction to cholesterol and bile acids and their subsequent excretion in faeces ${ }^{(52,53)}$. However, SOY was not hypocholesterolaemic compared to other proteins and whether such a mechanism accounts for the hypocholesterolaemic effect of WG remains to be investigated.

In conclusion, we have provided evidence that the source of dietary protein modulates cholesterol and fatty acid metabolism in hamsters, an animal model suitable to study the impact of diet on lipid metabolism, in the absence of dietary cholesterol and at fat intakes representative of the average Canadian diet. The present findings call for further investigation on the mechanisms of action of dietary protein with respect to lipid metabolism and suggest that dietary strategies aiming at preventing and/or managing CVD might need to take the source of the protein into consideration.

\section{Acknowledgements}

This work was supported in part by the Office of the Chief Scientist, Health Canada. A. A. and C. C.-H. are recipients of the Health Canada Office of Chief Scientist Postdoctoral Fellowship Award. The authors would like to thank Louise 
Plouffe, Carla Wood, Philip Griffin and Patrick Robertson for their technical advice and assistance. None of the authors had a conflict of interest.

\section{References}

1. Manuel DG, Leung M, Nguyen K, Tanuseputro P \& Johansen H (2003) Burden of cardiovascular disease in Canada. Can J Cardiol 19, 997-1004.

2. Smith ER (2003) The cost of illness. Can J Cardiol 19, 187-189.

3. Lichtenstein AH (2006) Thematic review series: patient-oriented research. Dietary fat, carbohydrate, and protein: effects on plasma lipoprotein patterns. J Lipid Res 47, 1661-1667.

4. Anderson JW, Konz EC \& Jenkins DJ (2000) Health advantages and disadvantages of weight-reducing diets: a computer analysis and critical review. J Am Coll Nutr 19, 578-590.

5. Krieger JW, Sitren HS, Daniels MJ \& Langkamp-Henken B (2006) Effects of variation in protein and carbohydrate intake on body mass and composition during energy restriction: a meta-regression 1. Am J Clin Nutr 83, 260-274.

6. Hu FB (2005) Protein, body weight, and cardiovascular health. Am J Clin Nutr 82, 242S-247S.

7. Anderson GH \& Moore SE (2004) Dietary proteins in the regulation of food intake and body weight in humans. J Nutr 134, 974S-979S.

8. Aziz A, Anderson GH, Giacca A \& Cho F (2005) Hyperglycemia after protein ingestion concurrent with injection of a GLP-1 receptor agonist in rats: a possible role for dietary peptides. $A m$ J Physiol Regul Integr Comp Physiol 289, R688-R694.

9. Kritchevsky D (1995) Dietary protein, cholesterol and atherosclerosis: a review of the early history. $J$ Nutr $125,589 \mathrm{~S}-593 \mathrm{~S}$.

10. Anderson JW, Johnstone BM \& Cook-Newell ME (1995) Metaanalysis of the effects of soy protein intake on serum lipids. $N$ Engl J Med 333, 276-282.

11. Carroll KK \& Kurowska EM (1995) Soy consumption and cholesterol reduction: review of animal and human studies. J Nutr 125, 594S-597S.

12. Bassat M \& Mokady S (1985) The effect of amino-acid-supplemented wheat gluten on cholesterol metabolism in the rat. Br J Nutr 53, 25-30.

13. Endo Y, Fu Z, Abe K, Arai S \& Kato H (2002) Dietary protein quantity and quality affect rat hepatic gene expression. $J$ Nutr 132, 3632-3637.

14. Shimada Y, Morita T \& Sugiyama K (2003) Increased response of liver microsomal delta 6-desaturase activity to dietary methionine in rats. Biosci Biotechnol Biochem 67, 743-751.

15. Sugiyama K, Ohkawa S \& Muramatsu K (1986) Relationship between amino acid composition of diet and plasma cholesterol level in growing rats fed a high cholesterol diet. J Nutr Sci Vitaminol (Tokyo) 32, 413-423.

16. Spady DK \& Dietschy JM (1983) Sterol synthesis in vivo in 18 tissues of the squirrel monkey, guinea pig, rabbit, hamster, and rat. J Lipid Res 24, 303-315.

17. Mendelson R, Tarasuk V, Chappell J, Brown H \& Anderson GH (2003) Report of the Ontario Food Survey. http:/www.ryerson. ca/ foodnut/facultyandstaff/Ontario_Food_Survey_Report_June_ 2003.pdf

18. Spady DK \& Dietschy JM (1988) Interaction of dietary cholesterol and triglycerides in the regulation of hepatic low density lipoprotein transport in the hamster. J Clin Invest 81, 300-309.

19. Jones PJ (1997) Regulation of cholesterol biosynthesis by diet in humans. Am J Clin Nutr 66, 438-446.

20. Shimomura I, Bashmakov Y, Shimano H, Horton JD, Goldstein JL \& Brown MS (1997) Cholesterol feeding reduces nuclear forms of sterol regulatory element binding proteins in hamster liver. Proc Natl Acad Sci U S A 94, 12354-12359.
21. Hayes KC, Stephan ZF, Pronczuk A, Lindsey S \& Verdon C (1989) Lactose protects against estrogen-induced pigment gallstones in hamsters fed nutritionally adequate purified diets. J Nutr 119, 1726-1736.

22. Association of Official Analytical Chemists (1990) Official Methods of Analysis, 15th ed. Arlington, VA: AOAC.

23. Sarwar G, Botting HG \& Peace RW (1988) Complete amino acid analysis in hydrolysates of foods and feces by liquid chromatography of precolumn phenylisothiocyanate derivatives. J Assoc Off Anal Chem 71, 1172-1175.

24. Bligh EG \& Dyer WJ (1959) A rapid method of total lipid extraction and purification. Can J Biochem Physiol 37, 911-917.

25. Banta CA, Warner RG \& Robertson JB (1975) Protein nutrition of the golden hamster. J Nutr 105, 38-45.

26. Blair RM, Appt SE, Netau-Pelissero C, Clarkson TB, Anthony MS, Lamothe V \& Potter SM (2002) Dietary soy and soy isoflavones have gender-specific effects on plasma lipids and isoflavones in golden Syrian $\mathrm{f}(1) \mathrm{b}$ hybrid hamsters. J Nutr 132, $3585-3591$.

27. Terpstra AH, Holmes JC \& Nicolosi RJ (1991) The hypocholesterolemic effect of dietary soybean protein $v s$. casein in hamsters fed cholesterol-free or cholesterol-enriched semipurified diets. J Nutr 121, 944-947.

28. Forsythe WA III (1995) Soy protein, thyroid regulation and cholesterol metabolism. J Nutr 125, 619S-623S.

29. Potter SM, Pertile J \& Berber-Jimenez MD (1996) Soy protein concentrate and isolated soy protein similarly lower blood serum cholesterol but differently affect thyroid hormones in hamsters. J Nutr 126, 2007-2011

30. Wright SM \& Salter AM (1998) Effects of soy protein on plasma cholesterol and bile acid excretion in hamsters. Comp Biochem Physiol B Biochem Mol Biol 119, 247-254.

31. Balmir F, Staack R, Jeffrey E, Jimenez MD, Wang L \& Potter SM (1996) An extract of soy flour influences serum cholesterol and thyroid hormones in rats and hamsters. $J$ Nutr 126, 3046-3053.

32. Trautwein EA, Liang J \& Hayes KC (1993) Plasma lipoproteins, biliary lipids and bile acid profile differ in various strains of Syrian hamsters Mesocricetus auratus. Comp Biochem Physiol Comp Physiol 104, 829-835.

33. Lewis GF \& Rader DJ (2005) New insights into the regulation of HDL metabolism and reverse cholesterol transport. Circ Res 96, $1221-1232$.

34. Rader DJ \& Maugeais C (2000) Genes influencing HDL metabolism: new perspectives and implications for atherosclerosis prevention. Mol Med Today 6, 170-175.

35. Horton JD, Bashmakov Y, Shimomura I \& Shimano H (1998) Regulation of sterol regulatory element binding proteins in livers of fasted and refed mice. Proc Natl Acad Sci U S A 95, 5987-5992.

36. Noguchi A, Takita T, Suzuki K, Nakamura K \& Innami S (1992) Effects of casein and soy-protein on alpha-linolenic acid metabolism in rats. J Nutr Sci Vitaminol (Tokyo) 38, 579-591.

37. Ratnayake WM, Sarwar G \& Laffey P (1997) Influence of dietary protein and fat on serum lipids and metabolism of essential fatty acids in rats. $B r J$ Nutr 78, 459-467.

38. Burdge GC \& Calder PC (2005) Conversion of alpha-linolenic acid to longer-chain polyunsaturated fatty acids in human adults. Reprod Nutr Dev 45, 581-597.

39. Nakamura MT \& Nara TY (2003) Essential fatty acid synthesis and its regulation in mammals. Prostaglandins Leukot Essent Fatty Acids 68, 145-150.

40. Blank C, Neumann MA, Makrides M \& Gibson RA (2002) Optimizing DHA levels in piglets by lowering the linoleic acid to alpha-linolenic acid ratio. J Lipid Res 43, 1537-1543. 
41. Harris WS \& Von SC (2004) The Omega-3 Index: a new risk factor for death from coronary heart disease? Prev Med 39, 212-220.

42. Kang JX \& Leaf A (2000) Prevention of fatal cardiac arrhythmias by polyunsaturated fatty acids. Am J Clin Nutr 71, 202S-207S.

43. Von SC (2000) $n-3$ fatty acids and the prevention of coronary atherosclerosis. Am J Clin Nutr 71, 224S-227S.

44. Goyens PL, Spilker ME, Zock PL, Katan MB \& Mensink RP (2006) Conversion of alpha-linolenic acid in humans is influenced by the absolute amounts of alpha-linolenic acid and linoleic acid in the diet and not by their ratio. Am J Clin Nutr 84, 44-53.

45. Goyens PL, Spilker ME, Zock PL, Katan MB \& Mensink RP (2005) Compartmental modeling to quantify alpha-linolenic acid conversion after longer term intake of multiple tracer boluses. J Lipid Res 46, 1474-1483.

46. Gilani GS \& Lee N (2003) Sources of food-grade protein. In Encyclopaedia of Food Sciences and Nutrition, pp. 4873-4879 [B caballero, L Trugo and P Finglas, editors]. New York: Academic Press.

47. Oda $H$ (2006) Functions of sulfur-containing amino acids in lipid metabolism. J Nutr 136, 1666S-1669S.
48. Morita T, Oh-hashi A, Takei K, Ikai M, Kasaoka S \& Kiriyama S (1997) Cholesterol-lowering effects of soybean, potato and rice proteins depend on their low methionine contents in rats fed a cholesterol-free purified diet. J Nutr 127, 470-477.

49. Sugiyama K, Yamakawa A, Kumazawa A \& Saeki S (1997) Methionine content of dietary proteins affects the molecular species composition of plasma phosphatidylcholine in rats fed a cholesterol-free diet. J Nutr 127, 600-607.

50. Cho HP, Nakamura MT \& Clarke SD (1999) Cloning, expression, and nutritional regulation of the mammalian Delta-6 desaturase. J Biol Chem 274, 471-477.

51. Kitts DD \& Weiler K (2003) Bioactive proteins and peptides from food sources. Applications of bioprocesses used in isolation and recovery. Curr Pharm Des 9, 1309-1323.

52. Gatchalian-Yee M, Imamura M, Nonaka M, Gu JY \& Sugano M (1994) Effect of dietary fats on cholesterol metabolism and eicosanoid production in hamsters fed undigested fraction of soybean protein. J Nutr Sci Vitaminol (Tokyo) 40, 499-504.

53. Gatchalian-Yee M, Arimura Y, Ochiai E, Yamada K \& Sugano M (1997) Soybean protein lowers serum cholesterol levels in hamsters: effect of debittered undigested fraction. Nutrition 13, 633-639. 